\title{
Ağrılı total diz artroplastisinin değerlendirilmesi
}

\author{
Evaluation of the painful total knee arthroplasty
}

\author{
Doğan Bek, Levent Gürer, Mustafa Başbozkurt
}

Gülhane Askeri Tıp Akademisi Ortopedi ve Travmatoloji Kliniği, Etlik, Ankara

\begin{abstract}
İlerlemiş osteoartritli hastalarda, ağrının giderilerek fonksiyonların geri kazanılması için yapılan total diz protezinde (TDP) oldukça başarılı sonuçlar bildirilmesine rağmen, $\% 20$ hastada ameliyat sonrası ağrının devam etmesi, hasta ve hekimi mutsuz etmektedir. Diz artroplasti sayısının eksponansiyel olarak artacağını göz önüne aldığımızda, düzeltici revizyonların gelecekte pratiğimizde daha önemli bir yer tutacağı açıktır. Ağrılı TDP'nin etiyolojisini ele almak ve değerlendirebilmek için, multidisipliner ve sistematik bir yaklaşım gerekmektedir. On adımlı, pratik bir tanısal yaklaşım, ayrıntılı analiz için tanımlanmış olup, ayrıntılı anamnez, ağrının tip analizi, psikolojik araştırma, omurga, kalça ve ayak bileği dahil kapsamlı klinik muayene, laboratuvar testleri, eklem aspirasyonu, infiltrasyon testi, radyografik analiz ve özel görüntüleme tekniklerini içerir. Bu tanısal algoritma kullanılarak, ağrılı TDP'li hastalarda başarısızlığın nedenleri ortaya konulabilir. Ağrılı TDP için hiçbir neden bulunamadıysa, revizyon cerrahisi yapılmamalıdır.
\end{abstract}

Anahtar sözcükler: diz ağrısı; total diz replasmanı; protez hata analizi
Total knee arthroplasty (TKA) is performed for eliminating the pain of the knee joint and regaining the knee joint function in patients with progressed knee osteoarthritis. However, patients and surgeons are unhappy because of ongoing pain in $20 \%$ of patients postoperatively. If we take into account the exponentially increasing number of the TKA's, it is apparent that corrective revisions will take an important place in our practice in the future. The evaluation and management of patients' pain should include a multidisciplinary and systematic approach. A practical 10-step diagnostic algorithm is described for failure analysis in more detail including an extended history, analysis of the type of pain, psychological exploration, thorough clinical examination including spine, hip and ankle, laboratory tests, joint aspiration, infiltration test, radiographic analysis and special imaging techniques. A sufficient failure analysis is possible by using this diagnostic algorithm in almost all patients with painful TKA. Furthermore, revision surgery shouldn't be performed if no cause is found for the painful TKA.

Key words: knee pain; total knee replacement; prosthesis failure analysis
T otal diz protezi (TDP), ilerlemiş gonartrozun tedavisinde altın standarttır. Primer TDP'nin etkinliği ve klinik başarısı kanıtlanmış olmasına rağmen, hastaların \%20'sinde görülen sürekli ağrı, hasta ve cerrah için mutsuzluk kaynağı olmasının ötesinde, sosyal ve adli bir takım problemlere de yol açabilmektedir. ${ }^{[1]}$ Enfeksiyon, aseptik gevşeme, dizilim bozukluğu gibi çeşitli etmenlerin ağrıyla ilişkisi bilinse de, \%4-13 hastada ağrının nedeninin bulunamadığı bildirilmiştir. ${ }^{[2,3]}$ Bu grup hastaların tedavisinin planlanması zordur ve ağrının gerçek nedeni bulunmadan yapılan revizyonların sonuçları ise yüz güldürücü değildir.
Dolayısıyla, gerçek neden bulunana kadar konservatif tedavide Israr edilmesi önerilmektedir. ${ }^{[4,5]}$ Revizyona giren TDP'lerin \%60-80'i, ilk 2-5 yıl içinde yapılmaktadır. ${ }^{[4,6]}$ Artan TDP sayısıyla birlikte, ağrısı devam eden hastaların sistematik olarak değerlendirilip ağrının gerçek nedeninin bulunması önem kazandığından, son yıllarda ayrıntılı algoritmalar geliştirilmiştir. ${ }^{[7,8,9]} \mathrm{Bu}$ yazının amacı, tanıya giden sürecin sistemleştirilip hata payının en aza indirilmesi için, ağrılı TDP olgularının değerlendirilmesini on temel basamağa ayırarak oluşturulmuş olan algoritma temel alınarak, güncel literatür bilgilerinin okuyucuya sunulmasıdır.

- İletişim adresi: Doç. Dr. Doğan Bek, Gülhane Askeri Tıp Akademisi, Ortopedi ve Travmatoloji Kliniği, Etlik, Ankara Tel: 0312 - 3045511 e-posta: doganbek@hotmail.com

- Geliștarihi: 8 Nisan $2015 \quad$ Kabul tarihi: 8 Nisan 2015 


\section{TANISAL ALGORITMA}

1. Ayrıntılı Hikaye

2. Ağrının Analizi

3. Psikolojik Araştırma

4. Klinik Değerlendirme

5. İnfiltrasyon

6. Laboratuvar Testleri

7. Aspirasyon

8. Radyoloji

9. Özel Görüntüleme Yöntemleri

10. Tedavi

\section{Ayrıntılı Hikaye}

Hastanın tüm tıbbi geçmişi, geçirdiği cerrahi süreci de içerecek şekilde incelenmelidir. Varsa, daha önce aldığı tıbbi tanılar (diabetes mellitus, romatoid artrit, psöriazis, immünsupresif tedavi, obezite, sigara), eğer başka bir merkezde ameliyat edilmişse sürecin nasıl gelişmiş olduğu (ameliyat süresi, bilinen bir problem yaşayıp yaşamadığı, hastanede kaldığı süre, uzamış yara akıntısı, kan transfüzyonu, kullanılan protezin tipi), ameliyat raporları, daha önce yapılan görüntüleme yöntemleri (X-ray, ultrasonografi [US], bilgisayarlı tomografi [BT], manyetik rezonans [MR], sintigrafi), laboratuvar testleri (seroloji, eklem aspiratları ve kültür sonucu), daha önce uygulanan tedaviler ve sonuçları, kronolojik sıra ile incelenmelidir.

Hastanın sosyokültürel durumu, alışkanlıkları, hobileri, mesleği ve ruhsal durumu değerlendirilerek, bunlarla ilgili olarak yüksek aktivite seviyesi veya beklentisi, emeklilik vb. ikincil kazanç beklentileri ve bunların mevcut şikayetler ile ilintisi irdelenmelidir.

\section{Ağrının Tipi}

Ağrılı TDP'de tanımlanan farklı ağrı tipleri, sıklıkla ağrının nedenine yönelik ipuçlarını bünyesinde barındırır (Tablo 1). ${ }^{[9-11]}$ Ağrıya neden olacak unsurları ise başlıca iki başlık altında inceleyebiliriz: 1) Tamamen diz ekleminden ve yapılan ameliyattan kaynaklanan intraartiküler nedenler ve 2) Uzak bölge problemlerinin dize yansıyan ağrılarının oluşturduğu ekstraartiküler nedenler (Tablo 2). Ağrının ne zaman başladığı, lokalizasyonu, karakteri, başlatan ya da arttıran/azaltan şeyler ve sıklı̆̆ı, nedene yönelik ipuçları taşır. Hastanın ameliyat öncesi ağrısı, ameliyat sonrası da aynı şekilde devam ediyorsa, ekstraartiküler nedenler akla gelmelidir ve muhtemelen yanlış bir TDP endikasyonu söz konusudur. Ayrıca, konservatif tedavi, ağrı kesiciler, egzersizler, stres testleri ve kullanılan breyslerin etkisi araştırılmalıdır. Ameliyat sonrası erken dönemde ağrı başlamış ise; bu ağrının, yetersiz yumuşak doku dengeleme, komponent malpozisyonu, yumuşak doku sıkışması, akut enfeksiyon ve instabiliteden kaynaklanıyor olması düşünülebilir. Ameliyattan sonrası ağrısız bir periyodu takiben geç dönemde başlayan ağrıda ise; polietilen aşınması, geç bağ instabilitesi, geç enfeksiyon ya da stres kırığı akla gelmelidir. Pozisyon değişikliği ile ani başlayan keskin ağrılar, daha çok mekanik kökenli sıkışma gibi nedenlerle oluşur; istirahatte oluşanlar ise, sıklıkla enfeksiyon nedenli ya da yansıyan nörojenik ağrılardır. Aktivite ile artan ağrılarda; gevşek komponent, instabilite, sıkışma ve tendinitler akla gelmelidir. Cilde dokunmakla oluşan elektrik çarpması gibi bir ağrı,

Tablo 1. Tarif edilen ağrı muhtemel nedenleri

\begin{tabular}{ll}
\hline Ağrı oluşumu & Nedenleri \\
\hline Gece ve istirahat ağrısı & Enfeksiyon, eklemde effüzyon veya nörojenik nedenler \\
Sandalyeden kalkarken veya merdiven inerken ağrı & Femur malrotasyon, fleksiyon aralık instabilitesi \\
Merdiven veya yokuş aşağı inerken ağrı & Fleksiyon aralığı instabilitesi \\
Ön diz ağrısı & Patellar maltreking, tendinit ve nörinom \\
Arka diz ağrısı & Posterior yumuşak dokunun gerginliği, popliteus tendinit \\
Ekstansiyonda ağrı & $\begin{array}{l}\text { Anterior yumuşak doku sıkışması, posterior gerginlik, posterior osteofit, fleksiyon- } \\
\text { ekstansiyon aralık uyumsuzluğu }\end{array}$ \\
Fleksiyonda ağrı & Posterior sıkışma (ofset/osteofitler), patella sıkışması veya gerginlik, malrotasyon \\
Hareket başlangıcında oluşan ağrı & Gevşek komponentler, tibia ve/veya femur forseps ağrısı \\
Yürümekle artan ağrı & Mekanik nedenler, enfeksiyon, nedeni bulunamayanlar
\end{tabular}


Tablo 2. Eklem içi ve dışı ağrı nedenleri

Ekstraartiküler Etkenler

1. Nörolojik

A. Spinal stenoz*

B. Lumbar radikülopati*

C. Nöroma

D. Kompleks bölgesel ağrı sendromu

2. Vasküler problemler*

3. Kalça osteoartriti*

4. Pes anserinus bursiti

5. Tendinopati*

A. Kuadriseps

B. Patellar

6. Stres kırı̆ı

A. Tibia

B. Patella

7. Periprostetik kırık

8. Heterotopik ossifikasyon

9. Diğer
A. Paget hastalığı
B. Pigmente villonodüler sinovit
C. Romatoid artrit
D. Ayak ve ayak bileği patolojileri

Intraartiküler Etkenler

1. Enfeksiyon*

2. Instabilite*

A. Mediolateral/Anteroposterior

B. Fleksiyon/Extansiyon

3. Malalignment*
A. Koronal/Sagittal

B. Rotasyonel

4. Aseptik gevşeme*

5. Protez fraktürü

6. Polietilen aşınma

7. Osteoliz*

8. Eklem sertliği

9. Yumuşak doku sıkışması

A. Patellar clunk

B. Popliteus sıkışması

C. Fabellar sıkışma

D. Komponent taşması

10. Ekstansör mekanizma*

A. Patellar maltracking

B. Patellar ağrı

i. Yüzeyi değiştirilmemiş patella

ii. Küçük patellar protez-lateral faset sıkışma

iii. Büyük patella-protez-PF eklem sıkışması

iv. Patella baja-alta

* Sık rastlanan nedenler.

nöromayı akla getirmelidir. Fizik muayene bulgularının ötesinde; şiddetli ağrı tarif eden, şişlik, eklem sertliği ve cilt değişiklikleri fark edilen hastalarda, kompleks bölgesel ağrı sendromu (KBAS) düşünülmelidir. Kalça, lumbal bölge, vasküler nedenlerle olabilecek, yansıyan veya ameliyat öncesi dönemde de var olan ekstraartiküler kökenli ağrılar da dikkatle değerlendirilmelidir.

\section{Psikolojik Araştırma}

Altı ay üzerinde kalıcı ağıısı olan hastalar, kronik ağrı hastaları olarak sınıflandırılır. Bozulmuş uyku düzeni, sıklıkla fibromiyalji ve psikolojik bozukluklarla birliktedir. Bunlar, hastanın eski problemleri olabileceği gibi, ameliyat sonrası ağrıya ikincil olarak da oluşabilir. Psikiyatrik bozuklukların varlığı, ağı nedeninin değerlendirilmesini ve tedaviye yanıtı da bozabileceğinden, multidisipliner yaklaşımlar tercih edilmelidir. Ameliyat öncesi dönemde psikolojik hastalık öyküsü olan veya ameliyat sonrası dönemde psikolojik profilinde değişiklik fark edilen hastaların (özellikle depresyon) tedavisinde, psikolojik ve psikofarmakolojik destek alınmalıdır. ${ }^{[12]}$ Klinik bulgular ile hastanın şikayeti uyumlu değilse, somatizasyon araştırılmalıdır. Bu gibi durumlarda revizyon cerrahisine gerek yoktur.

\section{Klinik Muayene}

Anamnez ile konulan ön tanının izleri, ayrıntılı yapılan fizik muayenede aranmalı ve yeni bulguları gözden kaçırmamak için inceleme yapılırken, ağrının kaynağını oluşturan intraartiküler veya ekstraartiküler nedenler akılda tutulmalıdır. ${ }^{[13]}$ Ağrılı diz eklemini değerlendirmeye, hastanın yürüme paterni, merdiven çıkması, sandalyeye desteksiz oturup kalkması ve diz çöküp kalkması gözlenerek başlanmalıdır. ${ }^{[14]}$ Fizik muayenede; aktif ve pasif eklem hareket açıklı̆ı (ROM), stabilite, şişlik, patellar uyum, ağrıyı tetikleyen durumlar ve cildin durumu, mutlaka incelenmesi gereken ana unsurlardır.

İnspeksiyonda diz eklemi etrafında eritem, şişlik, ISI artışı, sinus varlığı, enfeksiyon lehine; diz ve bacakta artrofi olması, ciltte koyuluk veya solukluk olması ise KBAS veya vasküler hastalıklar lehine yorumlanmalıdır. Tekrarlayan şişlikler; hemartroz $(\% 0,3-1,6)$, proliferatif sinovit, pigmente villonodüler sinovit (PVNS) veya pıhtılaşma bozukluklarından kaynaklanır. ${ }^{[8]}$ Koagülopatisi olmayan hastalarda, hemartrozisin en sık nedeni proliferatif sinoviyanın komponentler arasına sıkışmasıyla açılan damarların oluşturduğu kanamadır. Yalancı anevrizmaların hasarı, atherosklerotik 
damarların femoral komponent üzerinde erozyonu ve komponentlerin gevşemesine bağlı alttaki kemiğin kanamasına bağlı da hemartroz olduğu bildirilmiştir. ${ }^{[14,15]}$ Diz eklemi etrafindaki skar doku not edilmeli ve alt ekstremite diziliminde gözle görülür varusvalgus veya rotasyonel bir deformite olup olmadığı da grafilerden önce değerlendirilmelidir.

Palpasyonda ağrılı bölgelerin tespit edilerek bu bölge üzerine basılması ve ağrının tetiklenmesi, önemli ipuçları verebilir. Patellanın laterali boyunca tespit edilen hassasiyet, küçük patellar komponent kullanılması ile patellanın lateralindeki çıplak alanın femoral komponente basısıyla oluşan lateral faset sendromuna işaret edebilir. Mediyalden taşan tibial komponentin tahrişi ile mediyal kollateral bağ, pes anserinus veya popliteus tendon bölgesinde oluşan hassasiyet, bu bölgelerin palpasyonu ile ortaya konulabilir. Hassasiyet olmasa $\mathrm{da}$, dizin posterolateralinde fleksiyon-ekstansiyon sırasında klik veya krepitasyon hissi alınması, popliteus tendon sıkışması, fabellaya bağıı sıkışma ya da stress kırığını akla getirmelidir. Popliteus tendonunun sıkışması, lateral femoral kondil üzerinde kalan osteofitlere veya olması gerekenden büyük yerleştirilmiş femoral komponentin posterioruna bu tendonun teması ile oluşan ağrılı durumdur. ${ }^{[17,18]}$ İnsizyonun distal 1/3 mediyal bölgesindeki cilde yüzeyel temas ile oluşan elektriklenme tarzı ağrıda, aklımıza safen sinirin infrapatellar dalında oluşan nöroma gelmelidir. Bu ve benzer kutanöz nöromalarda, lokal anestezikler ile sinir blokajı yapılarak tanı konulabilir. ${ }^{[10]}$

Düz bacak kaldırma, aktif ve pasif ROM, dirence karşı ekstansiyon-fleksiyon ve patellar traking testleri yapılmalıdır. Stabilite analizi, tam ekstansiyon, 30$60-90^{\circ}$ fleksiyondaki diz ekleminin mediyal-lateral ve anterior-posterior stabilitesinin kontrolü ile yapılır. ${ }^{[19]}$ Otuz derece fleksiyonda yapılan diz eklem muayenesinde, kollateral bağlar muayene edilir. Eklem aralığında mediyal veya lateralde $5 \mathrm{~mm}$ üzerinde açılma olması frontal plan, ön-arka translasyon ise sagittal plan instabilitesini düşündürür. Ameliyat sonrası eklem hareket açıklığında, implant tasarımı ve hastanın ameliyat öncesi hareket açıklığı en önemli belirleyicilerdendir. Genel olarak $5^{\circ}$ 'nin üzerinde fleksiyon kontraktürü ve $95^{\circ}$ 'den daha az fleksiyon, hastalar için mutsuzluk kaynağıdır ve dizde sertlik olarak değerlendirilmelidir.

Ağrılı dizlerde patellofemoral problemler önemli bir yer tuttuğu için, muayene sırasında patella ayrıcalıklı bir önemi hak eder. Patellanın değiştirilip değiştirilmediği, fleksiyon-ekstansiyon sırasında patellanın seyri ve ekstansör mekanizmada bütünlüğün bozulup bozulmadığı veya ağrılı noktalar tanıya götürebilir. Patella değiştirilmiş ise; komponentin büyüklüğü, yerleşim yeri, patella rezeksiyon miktarı ve implantın kalınlığı, radyoloji bölümünde ayrıntısı verildiği üzere değerlendirilmelidir. Patellanın mobilitesi ve sıkılığı değerlendirilerek, grafilerde kalın implant ve büyük femoral komponent hataları aranmalıdır. Şüphe halinde, patellanın femoral oluktaki hareketi yüzeyi, değiştirilen ve değiştirilmeyen patellada kontrol edilerek, komponentlerin rotasyonlarının uygun olmayabileceği, radyolojik inceleme sırasında hatırlanmalıdır. Patellar kütleme (clunk) sendromu, suprapatellar nodül ile karakterize bir peripatellar fibröz doku proliferasyonudur. Bu sendrom, nodülün arka çapraz bağı kesen protezlerinin, özellikle ilk tasarımlarında, interkondiller bölgedeki kutucuğa fleksiyonda girip ekstansiyonda çıkması ile dışarıdan da duyulabilen bir ses ve ağrı oluşması ile karakterize, artroskopik olarak tedavi edilebilen bir problemdir. Muayene sırasında, ekstraartiküler ağrı nedenleri unutulmamalı ve lomber bölge, kalça eklemi, ayak bileği ve ayaktan kaynaklanabilecek problemler ayırt edilmelidir. Kalça ekleminde internal rotasyondaki kısıtılık, kalçada artroz ve dize yansıyan ağrıya neden olabileceği gibi; ciddi pesplanovalgus deformitesi, dizde valgus zorlanmaya ve mediyal kollateralde ağrı ve laksiteye neden olabilir.

\section{Infiltrasyon}

Lokal anestezik enjeksiyonu, ağrının intraartiküler ve ekstraartiküler nedenlerini ayırt etmek için kullanılır. Dize aspirasyon yapıldığında gelen sıvıda enfeksiyonu düşündürür; makroskopik bulgular yok ise, eklem içine lokal anestezik yapılmalıdır. Ağrının kaynağı intaartiküler ise, ağrı geçici olarak kesilir. Ekstraartiküler nedenlerde tetik nokta tespit edilerek, bu bölgeye yapılacak lokal anestezik, ayırıc tanıya yardımcı olabilir. iliosakral eklem infiltrasyonu veya sinir kök blokajı, omurilik kökenli diz ağrısını ayırt etmede yardımcı olur. Eğer KBAS'den şüpheleniyorsak, sempatik blokaj tanıya yardımcı olur. Ayrıca, değişik zamanlarda yapılan lokal anestezik ve plasebo enjeksiyonları, hastaların ikincil kazanç niyetlerini ortaya koymaya yardımcı olabilir.

\section{Laboratuvar Testleri}

Enfeksiyonu ekarte etmek için, eritrosit sedimentasyon hızı (ESR) ve C-reaktif proteine (CRP) mutlaka bakılmalıdır. ESR, ameliyat sonrası 5.-7. günde en üst düzeylere çıkar ve 3 . ayda normal döner. ${ }^{[20]}$ CRP ise 2.-3. gün en yüksek seviyeye ulaşıp, 3. haftada normal değerlere döner. Bir saatlik ESR $30 \mathrm{~mm}$ 'nin üstünde ve CRP normalin iki katı ise, enfeksiyon olasılı̆ıının \%80'in üzerinde olduğu bildirilmiştir. ${ }^{[21]}$ Yüksek CRP ve ESR değerlerinin kombinasyonu, 0,95 duyarlı, 0,93 özgül ve negatif prediktif değeri 0,97 'dir. ${ }^{[22]}$ Interlökin 6 (IL-6), enfeksiyon tanısında son yıllarda daha ümit 
verici bir serolojik test olarak gündemdedir. Serum düzeyleri, ameliyat sonrası 6.-12. saat gibi oldukça erken dönemde, ESR ve CRP'nin normal olduğu zaman diliminde hızla yükselir ve 48.-72. saat normale döner. IL-6 ve CRP kombinasyonu daha yüksek bir duyarlılık göstermektedir. ${ }^{[23]}$

\section{Aspirasyon}

Bütün ağrılı dizlerde enfeksiyon şüphesini gidermek için, en az 14 günlük antibiyotiksiz süreyi

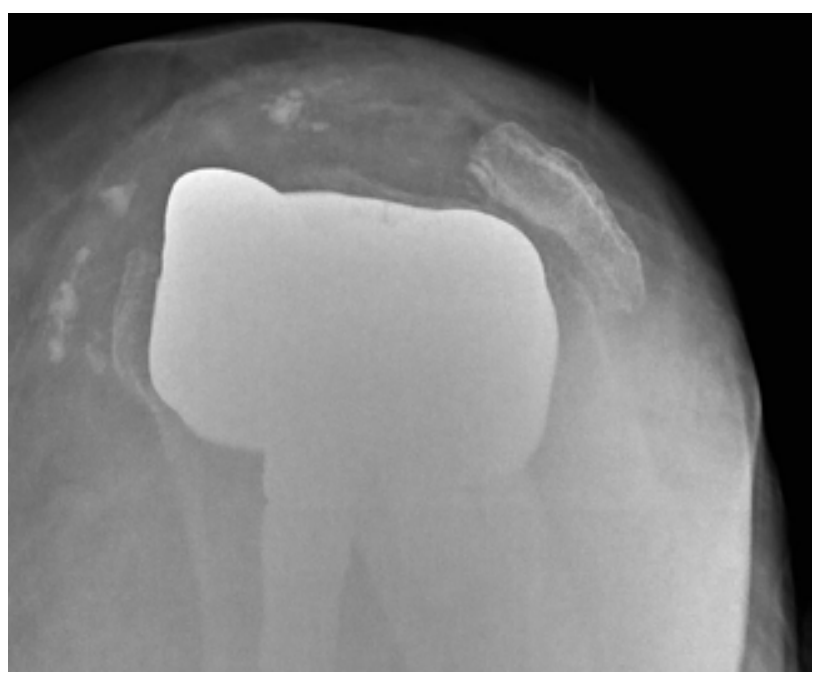

Şekil 1. Merchant grafisinde patellanın laterale luksasyonu. takiben, sinoviyal sıvının test edilmesi zorunludur. ${ }^{[24]}$ Aspirasyon, steril koşullar altında ve herhangi bir lokal anestezik olmaksızın yapılmalıdır. ${ }^{[25]}$ Aspirat hücre sayımı sonuçlarında, literatürde farklı rakamlar bildirilmekle beraber, lökositin 2,500 mm'den fazla olması ve \%60'tan fazla PMNL olması, düşük dereceli enfeksiyon tanısı için \%98 duyarı \%95 özgül bulunmuştur. ${ }^{[26]}$ Aerop ve anaerop etkenler için, bakteriyolojik analiz ve kültür yapılmalıdır. Aspirat, standart şartlarda, en az 14 gün süreyle inkübe edilmelidir. ${ }^{[27]}$ Pozitif kültür sonuçlarının hastanın kliniği ile uyumlu olması önemlidir. Negatif sonuca rağmen enfeksiyon şüphesi devam ediyorsa, antibiyotiksiz geçirilen süreyi uzatarak aspirasyonun tekrar edilmesinin daha doğru sonuçlar verdiği bildirilmiştir. Alınan aspiratta kontaminasyon şüphesinde, aspirasyon tekrar edilmelidir. Gram boyamanın tanı için güvenilirliği yoktur.

\section{Radyografik Analiz}

Radyografi, tanıda kullandığımız en temel araçlardan birisidir. Başlangıç olarak anterior-posterior grafi, lateral grafi ve yük altında aksiyel patella grafisi (Şekil 1), takiben alt ekstremitede kalça, diz ve ayak bileği eklemlerinin göründüğü dizilim grafisi çekilmelidir. Bu grafilerden; protezin tipi, alt ekstremitenin dizilimi, komponentlerin sagittal plandaki pozisyonu, komponentlerin boyutu ve taşma olup olmadığı, gevşeme, osteoliz, polietilenin aşınması (Şekil 2), eklem aralığının asimetrisi,

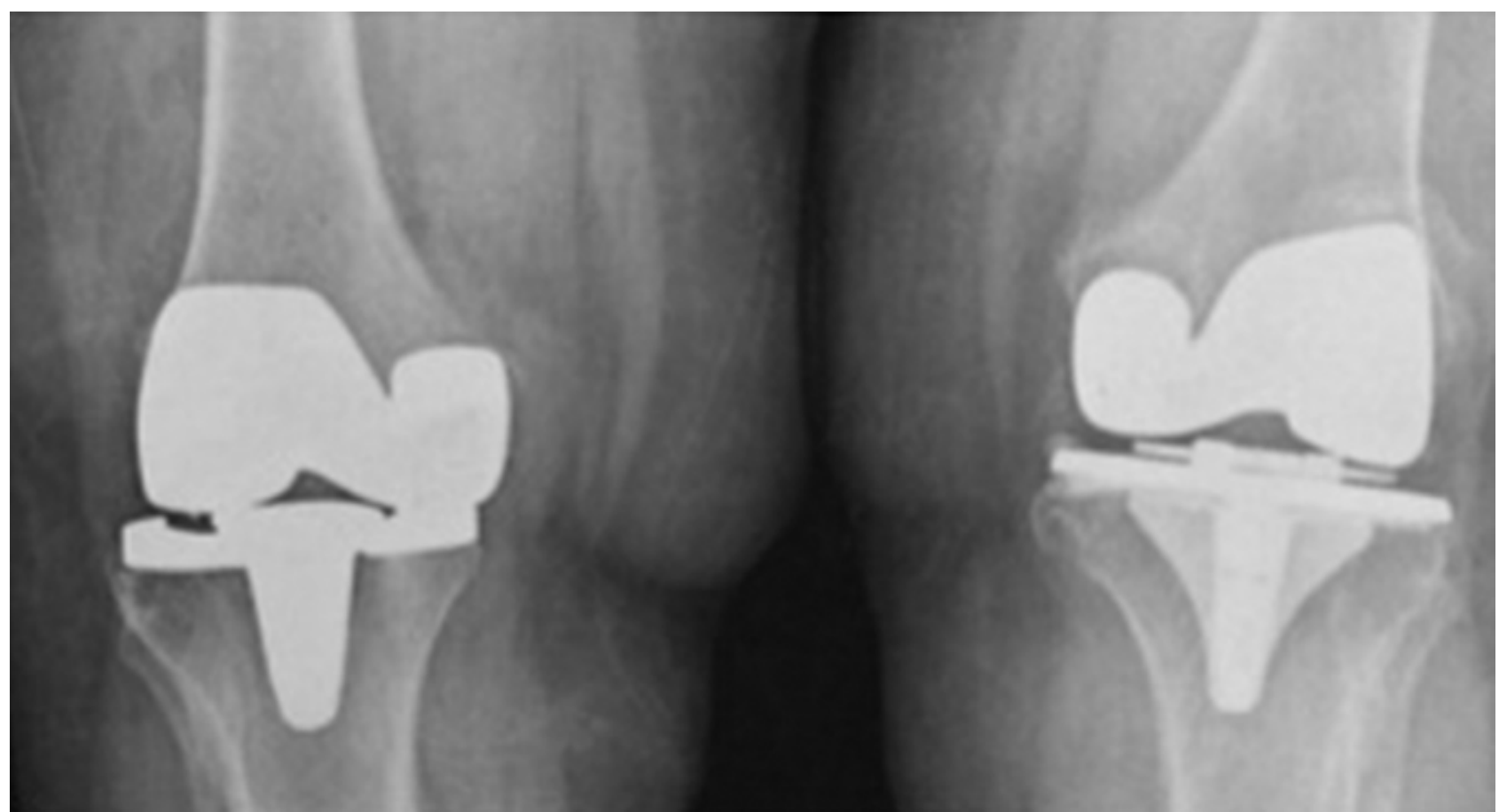

Şekil 2. Sağ dizde polietilen aşınmasına bağlı eklem aralığında asimetri. 
stres fraktürü, heterotofik ossifikasyon, yetersiz patella rezeksiyonu veya patellar tilt ya da subluksasyon gözlenebilir. ${ }^{\left[{ }^{[9]}\right.}$ Ameliyat öncesi grafilere ulaşmak mümkünse, eklem çizgisi, patellar yükseklik ve posterior femoral ofset değerlendirilebilir. Ameliyat öncesi grafiye ulaşmak mümkün değil ve diğer dize artroplasti yapılmamışsa, diğer diz grafisi ile değerlendirme yapılabilir. Küçük patellar komponent kullanılmasıyla oluşan lateral faset sendromu ve patella bajaya bağlı sıkışma, rutin grafilerde görebileceğimiz problemlerdir. Patellofemoral eklemde gerginliğe, dizde fleksiyon kısıtlılığına ve ağrıya neden olabilecek; femoral komponentin büyük olması veya anteriora translase yerleştirilmesi ve büyük patellar buton konulması, yan grafilerde karşı diz ile mukayese edilerek tespit edilebilir. Patellası değiştirilmemiş dizlerde de önemli bir problem olarak karşımıza çıkan ön diz ağrısını değerlendirmek için, Merchant grafisi mutlaka alınmalıdır.

Gevşemenin belirtisi, seri grafilerde ilerleyici radyolusens olmasıdır. Tibial komponentte daha çok varusa yönelim olurken, femoral komponentte, yan grafide artmış fleksiyon şeklinde karşımıza çıkabilir. Tibial ve patellar polietilen aşınmasını yük altında çekilen grafilerdeki asimetri ile tespit edebilirken, oluşan debrisin neden olduğu osteoliz birlikte görülebilir. Erken enfeksiyonlarda radyolojinin rolü sınılıyken, geç enfeksiyonlarda kemik rezorbsiyonu, periost reaksiyonu, yumuşak doku ya da eklem içinde gaz ve erken gevşeme bulguları görülebilir. Aseptik ve septik gevşemeyi ise, sadece klasik grafilerle ayırt etmek mümkün değildir. Floroskopi ile standart grafilerde göremediğimiz protez kırıkları veya gevşemeleri, protez ile kemik arayüzüne röntgen ışınlarını teğet gönderecek şekilde pozisyon

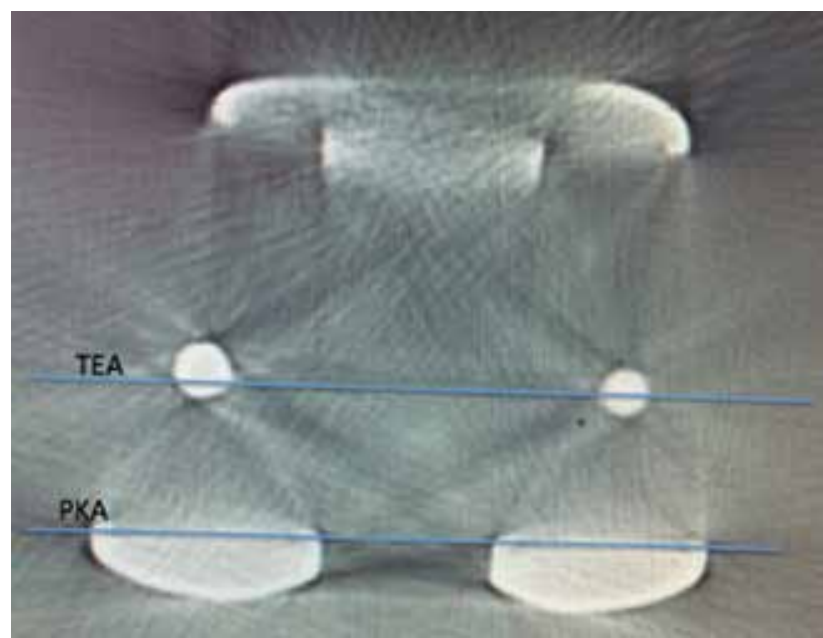

Şekil 3. Femurun aksiyel kesitinde transepikondiler aksis (TEA) posterior kondiler aksise (PKA) paralel ise rotasyon problemi yoktur. verilmesiyle tespit edilebilir. Stres grafileri, fleksiyon veya ekstansiyon gap instabilitesini ve dolaylı yoldan femoral komponent malrotasyonunu gösterebilir. ${ }^{[28]}$

\section{9. Özel Görüntüleme Teknikleri}

US yardımı ile yüzeye yakın dokular daha rahat değerlendirilebildiğinden, yumuşak dokudaki bir inflamasyon, tendon-bağ rüptürü ve yumuşak dokudaki şişliklerin tanısının konulmasında bu teknik kullanılabilir. Femur ve tibial komponentlerin internal rotasyonda yerleştirilmesi, en sık yapılan hatalardan birisidir ve patellar maltraking'e neden olarak instabilite ve ağrı kaynağı olabilir. Klinik muayene ve başlangıç grafilerinde malrotasyondan şüphelenebiliriz, ancak kesin tanı bu hastalara BT çekilerek konulabilir. Tomografi aksiyel kesitlerinde, femoral komponent epikondiler aksise paralel olması gerekirken (Şekil 3), tibial komponent tüberositaz tibianın $1 / 3$ mediyalinden geçmelidir (Şekil 4). Protez çevresinde, grafilerde görülen (veya göremediğimiz) radyolusen alanların gerçek genişliğinin tespiti ve periprostatik fissür şüphesi olan olgularda da BT taraması da yapılabilir. Sintigrafi, tarama testi olarak olarak değil, tanı doğrulama aracı olarak kullanılmalıdır. Ameliyattan sonra bir yıla kadar tutulum devam edeceğinden, üç fazlı kemik sintigrafisinin kullanımı sınırlı olmakla birlikte, elde edilecek negatif sonucun enfeksiyon ve gevşemeyi ekarte ettirmesi bakımından önemlidir. Üç fazlı teknesyum sintigrafi, indium işaretli beyaz küre sintigrafisi ve sülfür-kolloid marrow sintigrafi ise, birlikte kullanıldığında, enfeksiyon, aseptik gevşeme, KBAS Tip 1 ve stres kırığının ayırıcı tanılarında kullanılabilir. MR görüntülemenin yeni uygulamalarında, metal

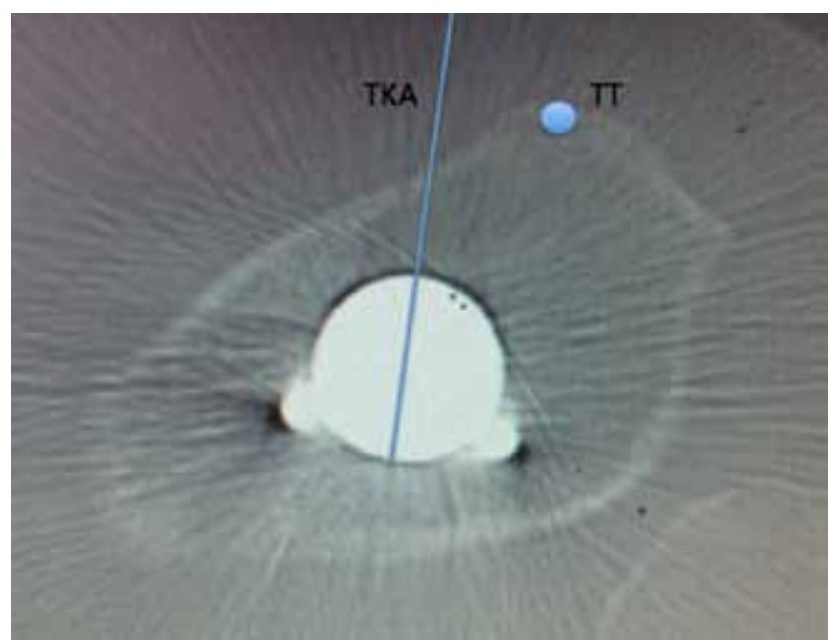

Şekil 4. Sol diz tibial komponent aksiyel kesiti. Tibial komponent Tüberositas tibianın (TT) en az 1/3 mediyalinden geçmesi gerekirken iç rotasyonda yerleştirilmiş. 
artefaktları baskılayan yöntemlerle protez çevresi osteolitik defeklerin değerlendirilmesinde tomografiye üstün sonuçların alınabileceği gösterilmiş olmakla birlikte, yöntem yaygınlaşmamıştır. ${ }^{[29]}$

\section{Konservatif Tedavi}

Ağrının nedeni olarak, enfeksiyon, gevşeme, kırık ya da implant kırılması gibi net bir neden ortaya konulamıyor ise, konservatif tedavi mutlaka denenmelidir. En az üç ay sürmesi önerilen bu süreç, analjezik tedavi, fizyoterapi, gerekirse breys vb. cihazlar ile desteklenmelidir. Ağrı nedeni, bir yandan kasa aşırı yüklenme olabileceği gibi, kasın az kullanılmasına bağlı atrofi oluşması da ağrıya neden olabileceğinden, buna yönelik günlük ev egzersizleri ve eğitim programları planlanmalıdır.

\section{SONUÇ}

Yaşam kalitesini yükseltmek maksadıyla yapılan TDP'de, devam eden ağrı her ne kadar hastayı mutsuz eden bir etmen ise de, gerçek nedene yönelik iyi planlama olmaksızın yapılan ve aynı hataların tekrarlanacağı revizyonların sonuçlarının hasta ve cerrah için daha ağır olacağı konusunda, literatürde fikir birliği vardır. ${ }^{[4,5]}$ Ağrının kaynağı ile ilgili olarak çok aşikar nedenler bulunabileceği gibi, daha az sıklıkla karşımıza çıkan olgularla da karşılaşabiliriz. Bu nedenle, hastalara sistematik yaklaşmak, doğru tanıya daha kısa sürede ulaşılmasını sağlayacaktır. Hofmann ve arkadaşları, 100 hastayı sistematik olarak değerlendirmişler, \%30 hastanın konservatif tedaviyle şikayetleri gerilediği ya da kalan şikayetlerini kabul edilebilir buldukları için revizyonu kabul etmediğini bildirmişlerdir. Hastaların \%5'inde ortaya bir neden konulamamış ve \%15 hastanın revizyon öncesi psikolojik desteğe ihtiyacı olmuştur. Revizyona giden \%65 hastada ise, en çok komponentlerde rotasyon problemleri (\%54), frontal planda dizilim bozukluğu (\%41), instabilite veya sertlik (\%36) revizyon nedeni olarak tespit edilmiştir. Hastaların \%50'sinde ise, iki veya daha fazla neden bulunmuştur. ${ }^{[10]}$ Yetmezlik nedenleri, intraartiküler ve ekstraartiküler olarak ayrılabilir.

Ağrılı TDP'de artroskopinin rolü sınırlıdır. Az invaziv bir girişim olması nedeniyle, tanısal amaçlı kullanılmamalıdır. Patellar clunk sendromu, popliteus tendon sıkışması, menisküs kalıntısı sıkışması ve artrofibrozis durumlarında ya da sement parçaları gibi serbest cisimlerin çıkarılması ve gergin arka çapraz bağı gevşetmek gerektiğinde artroskopi kullanılabilir.

Özetle, ağrılı dizin intraartiküler ve ekstraartiküler birçok nedeni mevcut olup, yapılacak revizyon, mutlaka ortaya konulan nedene yönelik yapılmalıdır.
Revizyon sırasında tespit edilen problemlerin hepsinin aynı seansta tedavisine yönelik bir plan yapılması gerekirken, açılanamayan ağrı nedeniyle yapılan revizyonların başarısız sonuçları akıldan çıkarılmamalıdır.

\section{KAYNAKLAR}

1. Bonnin MP, Basiglini L, Archbold HA. What are the factors of residual pain after uncomplicated TKA? Knee Surg Sports Traumatol Arthrosc 2011;19(9):1411-7. CrossRef

2. Elson DW, Brenkel IJ. A conservative approach is feasible in unexplained pain after total knee replacement: a selected cohort study. J Bone Joint Surg Br 2007;89(8):1042-5.

3. Brander VA, Stulberg SD, Adams AD, Harden RN, Bruehl S, Stanos SP, Houle T. Predicting total knee replacement pain: a prospective, observational study. Clin Orthop Relat Res 2003;(416):27-36.

4. Fehring TK, Odum S, Griffin L, Mason B, Nadaud M. Early failures in total knee arthroplasty. Clin Orthop Relat Res $2001 ;(392): 315-8$.

5. Toms AD, Mandalia V, Haigh R, Hopwood B. The management of patients with painful total knee replacement. J Bone Joint Surg Br 2009;91(2):143-50. CrossRef

6. Sharkey PF, Hozack WJ, Rothman RH, Shastri S, Jacoby SM. Insall award paper: why are total knee arthroplasty failing today? Clin Orthop Relat Res 2002;(404):7-13.

7. Allardyce TJ, Scuderi GR, Insall JN. Arthroscopic treatment of popliteus tendon dysfunction following total knee arthroplasty. J Arthroplasty 1997;12(3):353-5.

8. Hofmann S, Seitlinger G, Djahani O, Pietsch M. The painful knee after TKA. a diagnostic algorithm for failure analysis. Knee Surg Sports Traumatol Arthrosc 2011;19(9):1442-52. CrossRef

9. Djahani O, Rainer S, Pietsch M, Hofmann S. Systematic analysis of painful total knee prosthesis, a diagnostic algorithm. Arch Bone Jt Surg 2013;1(2):48-52.

10. Gonzalez $\mathrm{MH}$, Mekhail AO. The failed total knee arthroplasty: evaluation and etiology. J Am Acad Orthop Surg 2004;12(6):436-46.

11. Mandalia V, Eyres K, Schranz P, Toms AD. Evaluation of patients with a painful total knee replacement. J Bone Joint Surg Br 2008;90(3):265-71. CrossRef

12. Lingard EA, Riddle DL. Impact of psychological distress on pain and function following knee arthroplasty. J Bone Joint Surg Am 2007;89(6):1161-9.

13. Brown EC 3rd, Clarke HD, Scuderi GR. The painful total knee arthroplasty: diagnosis and management. Orthopedics 2006;29(2):129-36.

14. Kindsfater K, Scott R. Recurrent hemarthrosis after total knee arthroplasty. J Arthroplasty 1995;10 Suppl:S52-5.

15. Stanley D, Cumberland DC, Elson RA. Embolisation for aneurysm after knee replacement: brief report. J Bone Joint Surg Br 1989;71(1):138.

16. Larson JE, Becker DA. Fabellar impingement in total knee arthroplasty. A case report. J Arthroplasty 1993;8(1):95-7.

17. Allardyce TJ, Scuderi GR, Insall JN. Arthroscopic treatment of popliteus tendon dysfunction following total knee arthroplasty. J Arthroplasty 1997;12(3):353-5.

18. Barnes CL, Scott RD. Popliteus tendon dysfunction following total knee arthroplasty. J Arthroplasty 1995;10(4):543-5.

19. Parratte S, Pagnano MW. Instability after total knee arthroplasty. J Bone Joint Surg Am 2008;90(1):184-94. 
20. Bilgen O, Atici T, Durak K, Karaeminoğullari, Bilgen MS. C-reactive protein values and erythrocyte sedimentation rates after total hip and total knee arthroplasty. J Int Med Res 2001;29(1):7-12.

21. Della Valle C, Parvizi J, Bauer T, Di Cesare P, Evans R, Segreti J, Spangehl M. The diagnosis of periprosthetic joint infections of the hip and knee: guideline and evidence report. Rosemont IL: AAOS Clinical Practice Guidlines Unit, American Academy of Orthopedic Surgeons; 2010. p.1-286.

22. Greidanus NV, Masri BA, Garbuz DS, Wilson SD, McAlinden MG, Xu M, Duncan CP. Use of erythrocyte sedimentation rate and $\mathrm{C}$-reactive protein level to diagnose before revision total knee arthroplasty: a prospective evaluation. J Bone Joint Surg Am 2007;89(7):1409-16.

23. Bottner F, Wegner A, Winkelmann W, Becker K, Erren M, Götze C. Interleukin-6, procalcitonin and TNF alpha: markers of periprosthetic infection following total joint replacement. J Bone Joint Surg Br 2007;89(1):94-9.

24. Barrack RL, Jennings RW, Wolfe MW, Bertot AJ. The Coventry Award. The value of preoperative aspiration before total knee revision. Clin Orthop Relat Res 1997;(345):8-16.
25. Fink B, Makowiak C, Fuerst M, Berger I, Schäfer P, Frommelt $\mathrm{L}$. The value of synovial biopsy, joint aspiration and C-reactive protein in the diagnosis of late peri-prosthetic infection of total knee replacements. J Bone Joint Surg Br 2008;90(7):8748. CrossRef

26. Mason JB, Fehring TK, Odum SM, Griffin WL, Nussman DS. The value of white blood cell counts before revision total knee arthroplasty. J Arthroplasty 2003;18(8):1038-43.

27. Schäfer P, Fink B, Sandow D, Margull A, Berger I, Frommelt L. Prolonged bacterial culture to identify late periprosthetic joint infection: a promising strategy. Clin Infect Dis 2008;47(11):1403-9. CrossRef

28. Stähelin T, Kessler O, Pfirrmann C, Jacob HA, Romero J. Fluoroscopically assisted stress radiography for varus-valgus stability assessment in flexion after total knee arthroplasty. J Arthroplasty 2003;18(4):513-5.

29. Sofka CM, Potter HG, Figgie M, Laskin R. Magnetic resonance imaging of total knee arthroplasty. Clin Orthop Relat Res 2003;(406):129-35. 